\title{
Sistem Pendukung Keputusan Optimasi Biaya Dan Rute Pengiriman Barang Dengan Multimoda Menggunakan Algoritma Kruskal Dalam Optimasi Single Moda
}

\author{
Lady Silk M \\ Teknik Telekomunikasi dan Navigasi Udara, Politeknik Penerbangan Surabaya \\ Jl Jemur Andayani I/73, Surabaya 60236 \\ Email : ladysilkmoonlight@ymail.com
}

\begin{abstract}
ABSTRAK
Indonesia merupakan negara kepulauan terbesar didunia dengan lebih dari 17 ribu pulau. Untuk Negara yang terdiri dari kepulauan dan lautan ini dibutuhkan sistem angkutan antar moda, yang menghubungkan antar pulau yang tersebar, demi menciptakan sistem transportasi yang aman, efektif dan efisien. Pengiriman barang merupakan salah satu proses logistik yang utama, sehingga penting untuk dikaji lebih dalam. Dalam proses pengiriman barang, dibutuhkan suatu sistem yang dapat memberi gambaran tentang waktu dan biaya angkutan multimoda yang paling efektif dan efisien. Pada penelitian ini, dibangun Sistem Informasi yang dapatmembantu user dalammengambil keputusan untuk mengoptimalkan waktudan biaya pengiriman barang, sehingga dapat menunjukan segala kemungkinan multimoda yang dapat digunakan dalam proses pengiriman barang. Sistem Multimoda yang diterapkan yaitu angkutan dari pabrik menuju ke pangkal jalur utama pertama pada suatu kota asal (stasiun kereta api, kargo pesawat udara, kargo pelabuhan kapal laut) menuju lokasi tujuan/transit. Danangkutan dari jalur utama pada kota tujuan/transit menuju gudang, atau menuju jalur utama selanjutnya. Pada sistem informasi ini, hal yang dipertimbangkan adalah biaya dan waktu perjalanannya dari 4 moda, yaitu Darat, Laut, Udara dan Kereta Api, dengan mempertimbangkan segala kemungkinan multimoda yang dapat digunakan. Sistem ini juga dapat menghitung untuk lokasi tujuan yang hanya dapat dilalui moda tertentu saja. Pada perhitungan single moda, digunakan Algoritma Kruskal dalam perhitungan rute terpendek.
\end{abstract}

Kata Kunci : Sistem Infoprmasi, Transportasi, Multimoda, Algoritma Kruskal.

\section{PENDAHULUAN}

Indonesia merupakan negara kepulauan terbesar sedunia dengan lebih dari 17 ribu pulau didalamnya yang harus tehubung dengan baik melalui sistem transportasi yang baik pula. Dengan kondisi Indonesia yang terdiri dari kepulauan dan lautan, maka moda transportasi terbaik adalah angkutan multimoda. Sehingga kebutuhan angkutan antar moda pun akan saling melengkapi untuk menciptakan sistem transportasi yang ideal demi menciptakan sistem transportasi yang aman, efektif dan efisien.

Sistem transportasi yang baik merupakan wujud dari sistem logistik yang baik pula. Namun, dari data surve Logistic Performance Index oleh Bank Dunia melalui website http://pisurvey.worldbank.org/ terlihat bahwa kinerja logistik Nasional Indonesia berada diperingkat 53 dari 160 Negara yang disurvei. Posisi ini jauh dibawah Negara tetangga seperti Singapura, Malaysia dan Thailand. Walaupun demikian, sejak survei dilakukan kali pertama, posisi ini semakin tahun semakin meningkat, dan bukan hal mustahil jika sistem logistik Indonesia akan dapat lebih baik dari Negara ASEAN lainnya.

Dari arti pentingnya sistem angkutan multimoda dan Sistem Logistik Indonesia yang terus berkembang, terutama dalam pengiriman barang, maka dibutuhkan suatu sistem yang dapat 
memberi gambaran tentang waktu dan biaya angkutan multimoda yang paling efektif dan efisien. Sehingga sistem tersebut dapat membantu dalam mengambil keputusan pelaku distribusi. Algoritma kruskal merupakan salah satu algoritma yang dapat digunakan untuk mencari lintasan dalam menenentukan banyaknya lintasan yang dapat dilalui, serta menentukan lintasan terpendeknya. Pada penelitian ini, digunakan Algoritma kruskal dalam membangun sistem pendukung pendukung keputusan optimasi biaya dan rute pengiriman barang.

\section{PEMBAHASAN}

\section{Multimoda}

Angkutan multimoda dalam Peraturan Pemerintah No 8 Tahun 2011 tentang Angkutan Multimoda, didefinikan sebagai, "Angkutan Multimoda adalah angkutan barang dengan menggunakan paling sedikit 2 (dua) moda angkutan yang berbeda atas dasar 1 (satu) kontrak sebagai dokumen angkutan multimoda dari satu tempat diterimanya barang oleh badan usaha angkutan multimoda ke suatu tempat yang ditentukan untuk penyerahan barang kepada penerima barang angkutan multimoda." Angkutan multimoda perlu digunakan sebagai pengiriman untuk menghemat biaya perjalanan.

\section{Logistik}

Logistik dalam blueprint Penataan Dan Pengembangan Sektor Logistik Indonesia (2008) didefinisikan sebagai penyediaan suatu barang yang dibutuhkan yang pengadaannya dapat dilakukan langsung oleh pihak yang membutuhkan atau dilakukan oleh pihak lain.

\section{Algoritma Kruskal}

Algoritma Kruskal merupakan salah satu algoritma untuk menentukan lintasan terpendek. Pada algoritma kruskal, sisi graf diurut terlebih dahulu berdasarkan bobotnya dari yang terkecil hingga terbesar, dan penambahan sisi yang dipilih tidak boleh membentuk sirkuit (siklus).

Langkah - langkah algoritma kruskal :

(Asumsi: sisi-sisi dari graf sudah diurut menaik berdasarkan bobotnya, dari bobot kecil ke bobot besar)

$T$ masih kosong

Pilih sisi $(u, v)$ dengan bobot minimum yang tidak membebtuk sirkuit di T. Tambahkan $(u, v)$ ke dalam $T$.

ulangi langkah dua sebanyan $n-1$ kali.

Dalam notasi pseude-code, algoritma kruskal sebagai berikut:

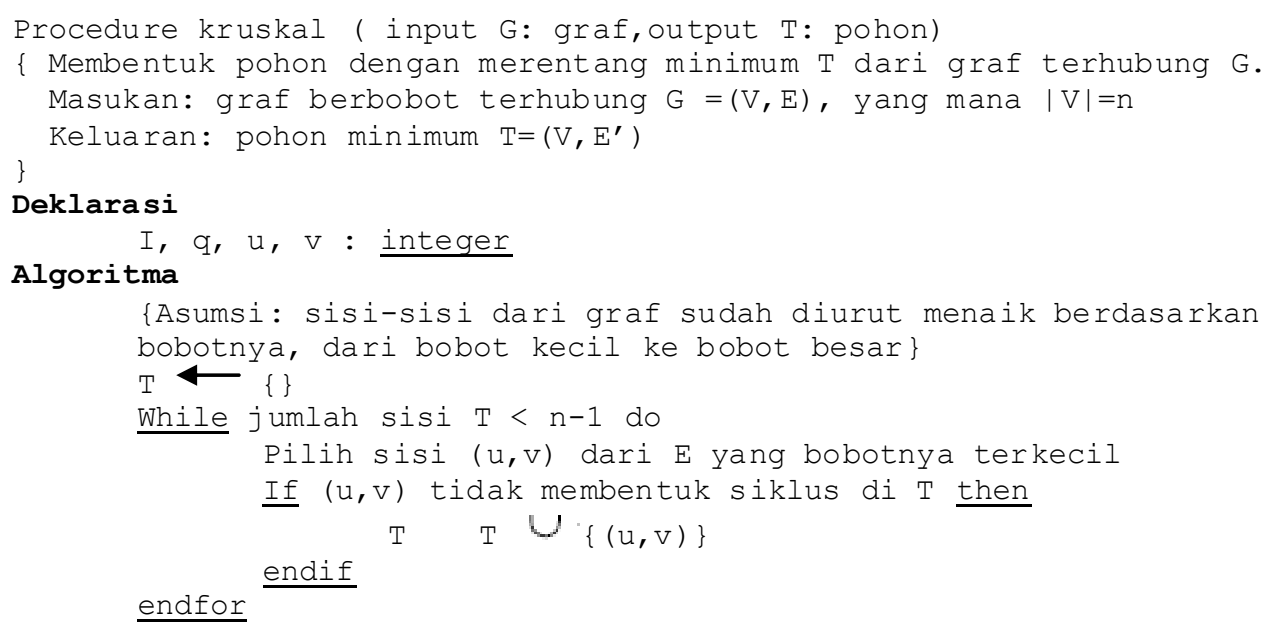




\section{Alur Transportasi Multimoda Pengiriman Barang}

Berikut adalah diagram alur angkutan transportasi multimoda dari pabrik di kota asal menuju kota tujuan untuk didistribusikan ke semua took dengan 1 Jalur Utama. Angkutan multimoda digunakan Dari kota asal ke kota tujuan. Sedangkan angkutan satu moda digunakan untuk distribusi dalam kota atau luar kota.

\begin{tabular}{|c|c|c|c|}
\hline $\begin{array}{c}\text { PABRIK KE } \\
\text { TERMINAL/STASIUN/KARGO } \\
\text { DENGAN TRUCK }\end{array}$ & $\begin{array}{c}\text { JALUR UTAMA } \\
\text { ANTAR KO TA }\end{array}$ & $\begin{array}{c}\text { TERMINAL/STASIUN/KARGO } \\
\text { KE GUDANG DENGAN TRUCK }\end{array}$ & $\begin{array}{c}\text { DISTRIBUSI } \\
\text { ANTAR TO KO }\end{array}$ \\
\hline \multirow{3}{*}{ DARAT } & LAUT & & \multirow{2}{*}{ DARAT } \\
\cline { 2 - 2 } & UDARA & DARAT & \\
\cline { 2 - 2 } & KERETA API & & \\
\cline { 2 - 2 } & DARAT & & \\
\hline
\end{tabular}

Dalam kasus ini dimisalkan kesatuan gambaran lokasi dan rute adalah Graf, dimana tempat singgah atau perpindahan moda, kota atau toko yang dikunjungi, adalah Simpul dari Graf, dan jarak serta biaya adalah himpunan sisi dari Graf, maka gambar dari Graf dapat dimisalkan sebagai berikut:

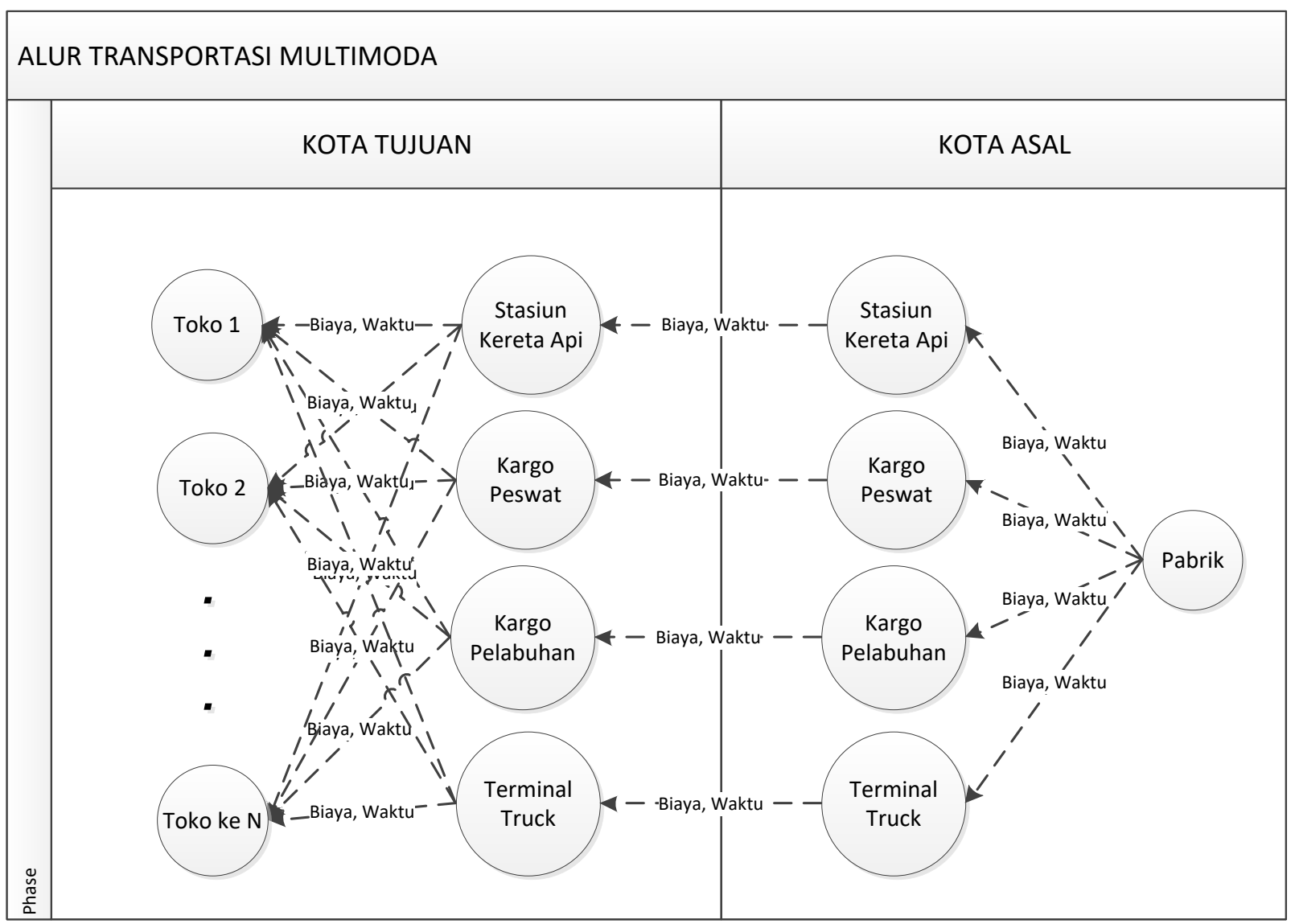

Gambar 1 Graf Antar Titik Pengambilan Barang

Namun jika distribusi terjadi antara tempat asal dan tujuan melewati lebih dari 1 jalur utama, maka tabel moda transportasi dapat menjadi seperti berikut. 
Tabel 2 Moda dengan Jalur Utama lebih dari 1

\begin{tabular}{|c|c|c|c|c|c|c|c|}
\hline $\begin{array}{l}\text { PABRIK KE } \\
\text { TERMINAL } 1 \\
\text { DENGAN } \\
\text { TRUCK } \\
\end{array}$ & $\begin{array}{c}\text { JALUR UTAMA } \\
1 \text { ANTAR } \\
\text { KOTA }\end{array}$ & $\begin{array}{c}\text { TERMINAL } \\
2 \text { KE } \\
\text { TERMINAL } \\
3 \\
\end{array}$ & $\begin{array}{c}\text { JALUR } \\
\text { UTAMA } 2 \\
\text { ANTAR } \\
\text { KOTA }\end{array}$ & $\begin{array}{c}\text { TERMINAL } \\
4 \text { KE } \\
\text { TERMINAL } \\
5 \\
\end{array}$ & $\begin{array}{c}\text { JALUR } \\
\text { UTAMA } 3 \\
\text { ANTAR } \\
\text { KOTA } \\
\end{array}$ & $\begin{array}{c}\text { TERMINAL } \\
4 \text { KE } \\
\text { TERMINAL } \\
5\end{array}$ & $\begin{array}{c}\text { DISTRIB US } \\
\text { I ANTAR } \\
\text { TOKO }\end{array}$ \\
\hline \multirow{4}{*}{ DARAT } & LAUT & \multirow{4}{*}{ DARAT } & LAUT & \multirow{4}{*}{ DARAT } & LAUT & \multirow{4}{*}{ DARAT } & \multirow{4}{*}{ DARAT } \\
\hline & UDARA & & UDARA & & UDARA & & \\
\hline & KERETA API & & KERETA API & & $\begin{array}{l}\text { KERETA } \\
\text { API }\end{array}$ & & \\
\hline & DARAT & & DARAT & & DARAT & & \\
\hline
\end{tabular}

Terminal merupakan Terminal Truck, Stasiun Kereta Api, Kargo Pesawat Udara atau Kapal Laut.

\section{Flowchart System}

Flowchart system merupakan gambar alur penentuan moda untuk distribusi antar kota dalam atau luar pulau, dari gudang pada kota asal menuju gudang pada kota tujuan. Pada jalur utama ini, moda yang digunakan dapat lebih dari 1 moda di lebih dari 1 jalur utama. Moda yang akan dipertimbangkan yaitu moda darat, laut, udara dan kereta.

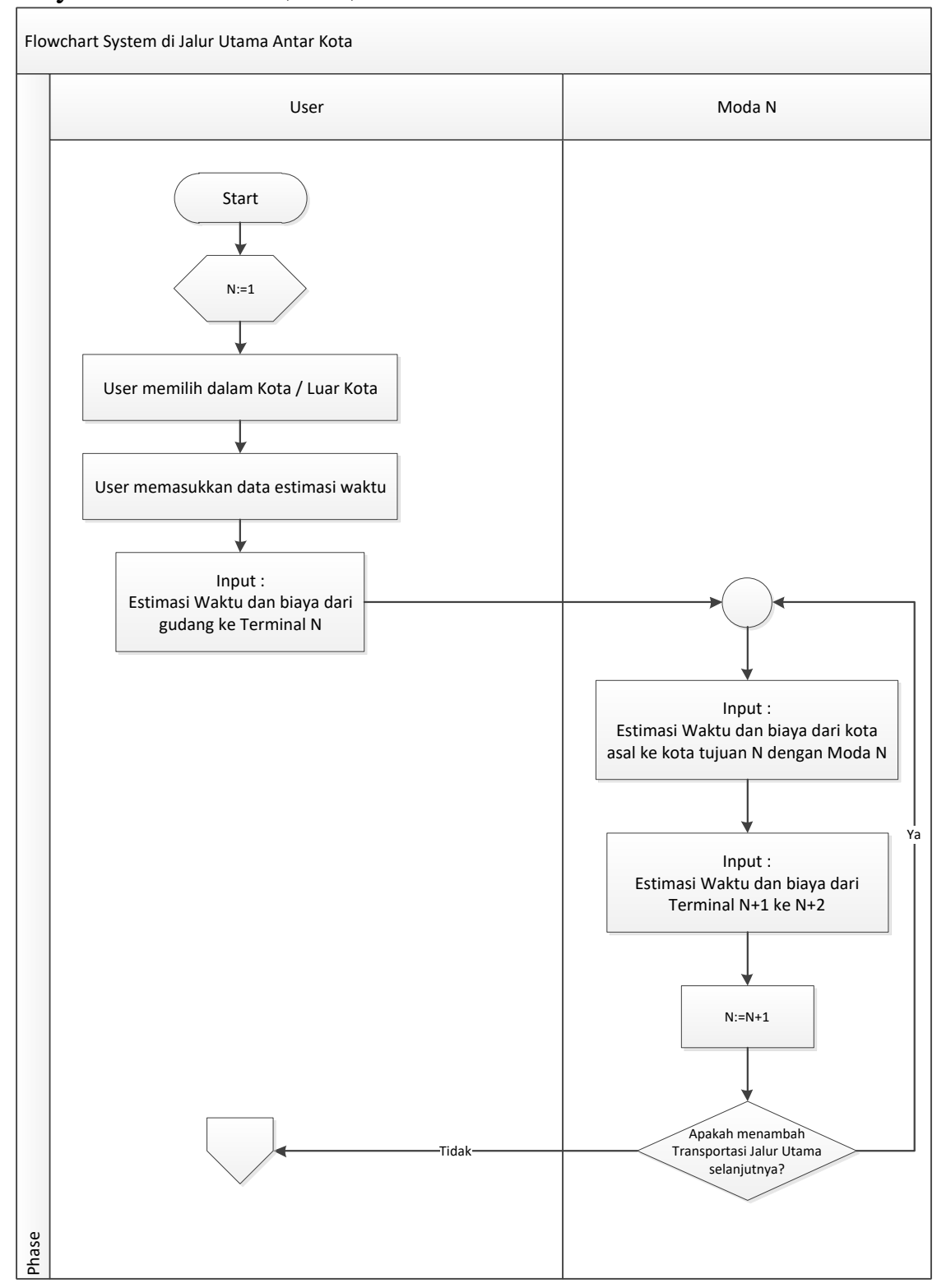


Gambar Flowchart Jalur Utama

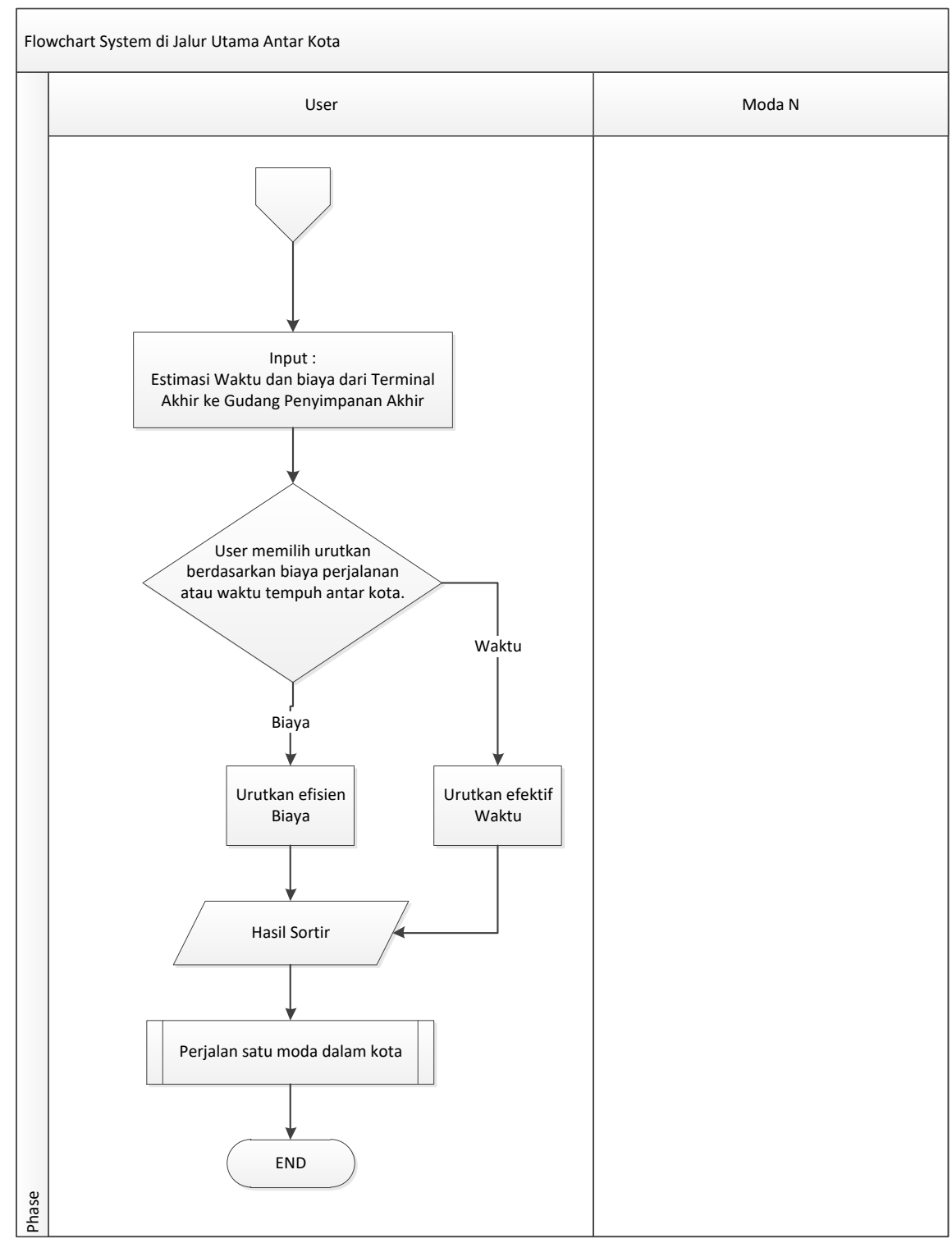

Gambar Flowchart Jalur Utama

\section{Implementasi System dan Analisa}

Berikut disimulasikan perhitungan perjalanan pengiriman barang seberat $5000 \mathrm{Kg}$ dari Surabaya ke Jakarta. Perjalanan dari Surabaya ke Jakarta hanya ditempuh dengan 1 jalur utama. Perjalanan ini dapat ditempuh menggunakan moda darat, laut, udara, atau kereta api. Setiap moda memiliki biaya jasa pengiriman berbeda-beda. Nilai masukan/inputan user dapat berupa nilai estimasi.

Keterangan :

$\square$ Nilai Inputan

Nilai Input / Tetapan dari Inisialisasi

Nilai Hasil Perhitungan / Pengolahan data lainnya.

Kota Asal

Kota Tujuan
: Surabaya

: Banyuwangi 


$\begin{array}{llll}\text { Daya Angkut 1 Truk } & : & 1000 & \mathrm{~kg} \\ \text { Biaya Angkut Truk /10 } & \mathrm{Rp} & \\ \mathrm{km} & : & 20,000 & \\ \text { Berat Barang } & : & 5000 & \mathrm{~kg}\end{array}$

\section{Perjalanan dari Pabrik Ke Terminal 1}

Diasumsikan perjalanan pengiriman barang dari pabrik ke kargo dengan moda transportasi darat ke pangkalan masing-masing Terminal, yaitu dapat berupa terminal Truck, Dermaga Pelabuhan Kapal Laut, Bandar Udara atau Stasiun Kereta Api. Berikut simulasi perhitungannya:

\begin{tabular}{|l|l|l|l|l|l|}
\hline \multirow{2}{*}{ No } & Moda & $\begin{array}{c}\text { Jarak Pabrik } \\
\text { ke Kargo } \\
(\mathbf{k m})\end{array}$ & $\begin{array}{c}\text { Biaya } \\
\text { Perjalanan } \\
\text { (Rp) Per Truck }\end{array}$ & $\begin{array}{c}\text { Jumlah } \\
\text { Truck } \\
\text { Angkut }\end{array}$ & $\begin{array}{c}\text { Lama } \\
\text { Perjalanan } \\
\text { (Menit) }\end{array}$ \\
\hline 1 & Darat & 10 & 100,000 & 5 & 40 \\
\hline 2 & Laut & 15 & 100,000 & 5 & 60 \\
\hline 3 & Udara & 20 & 100,000 & 5 & 120 \\
\hline 4 & Kereta Api & 10 & 100,000 & 5 & 40 \\
\hline
\end{tabular}

\section{Perjalanan Jalur Utama 1}

Diasumsikan perjalanan pengiriman barang di jalur utama antar Kota dapat menggunakan moda Darat, Laut, Udara atau Kereta Api. Penetapan biaya jasa pengiriman kargo yaitu per Kilogram. Berikut simulasi perhitungannya:

\begin{tabular}{|c|c|c|c|}
\hline \multirow[b]{2}{*}{ No } & \multirow[b]{2}{*}{ Moda } & \multicolumn{2}{|c|}{ JALUR UTAMA } \\
\hline & & $\begin{array}{c}\text { Biaya } \\
\text { Kargo Per } \\
\text { Kg }\end{array}$ & $\begin{array}{c}\text { Lama } \\
\text { Perjalanan } \\
(\text { Jam) }\end{array}$ \\
\hline 1 & Darat & 1,000 & 72 \\
\hline 2 & Laut & 3,000 & 72 \\
\hline 3 & Udara & 9,000 & 48 \\
\hline 4 & Kereta Api & 2,000 & 72 \\
\hline
\end{tabular}

\section{Perjalanan dari Terminal 2 ke Terminal 3}

Diasumsikan perjalanan pengiriman barang di jalur utama antar Kota dapat menggunakan moda Darat, Laut, Udara atau Kereta Api. Penetapan biaya jasa pengiriman kargo yaitu per Kilogram. Berikut simulasi perhitungannya:

\begin{tabular}{|l|l|r|r|r|}
\hline \multirow{2}{*}{ No } & Moda & $\begin{array}{c}\text { TERMINAL 2 - TERMINAL 3 } \\
\text { Biaya Perjalanan } \\
\text { (Rp) Per Truck }\end{array}$ & $\begin{array}{c}\text { Jumlah Truck } \\
\text { Angkut }\end{array}$ & $\begin{array}{c}\text { Lama } \\
\text { Perjalanan } \\
\text { (Menit) }\end{array}$ \\
\hline 1 & Darat & 100,000 & 5 & 50 \\
\hline
\end{tabular}




\begin{tabular}{|l|l|l|l|l|}
2 & Laut & 100,000 & 5 & 70 \\
\hline 3 & Udara & 100,000 & 5 & 130 \\
\hline 4 & Kereta Api & 100,000 & 5 & 50 \\
\hline
\end{tabular}

\section{Perjalanan Jalur Utama 2}

Diasumsikan perjalanan pengiriman barang di jalur utama antar Kota dapat menggunakan moda Darat, Laut, Udara atau Kereta Api. Penetapan biaya jasa pengiriman kargo yaitu per Kilogram. Berikut simulasi perhitungannya:

\begin{tabular}{|c|c|c|c|}
\hline \multirow[b]{2}{*}{ No } & \multirow[b]{2}{*}{ Moda } & \multicolumn{2}{|c|}{ JALUR UTAMA 2} \\
\hline & & $\underset{\text { Bg }}{\text { Biaya }}$ & $\begin{array}{c}\text { Lama Perjalanan } \\
(\mathrm{Jam})\end{array}$ \\
\hline 1 & Darat & 1,500 & 9 \\
\hline 2 & Laut & 3,000 & 10 \\
\hline 3 & Udara & 9,000 & 3 \\
\hline 4 & Kereta Api & 2,000 & 9 \\
\hline
\end{tabular}

\section{Perjalanan dari Kargo Ke Pabrik}

Diasumsikan perjalanan pengiriman barang dari kargo ke gudang penyimpanan barang menggunakan moda transportasi darat. Berikut simulasi perhitungannya:

\begin{tabular}{|l|l|l|l|l|l|}
\hline \multirow{2}{*}{ No } & Moda & $\begin{array}{c}\text { Jarak Kargo } \\
\text { ke Gudang } \\
(\mathbf{k m})\end{array}$ & $\begin{array}{c}\text { Biaya } \\
\text { Perjalanan } \\
\text { (Rp) Per } \\
\text { Truck }\end{array}$ & $\begin{array}{c}\text { Jumlah } \\
\text { Truck } \\
\text { Angkut }\end{array}$ & $\begin{array}{c}\text { Lama } \\
\text { Perjalanan } \\
\text { (Menit) }\end{array}$ \\
\hline 1 & Darat & 15 & 100,000 & 5 & 50 \\
\hline 2 & Laut & 20 & 100,000 & 5 & 150 \\
\hline 3 & Udara & 30 & 100,000 & 5 & 300 \\
\hline 4 & Kereta Api & 15 & 100,000 & 5 & 50 \\
\hline
\end{tabular}

\section{Hasil}

Berikut hasil perhitungan biaya dan lama perjalanan di Jalur Utama pengiriman antar kota.

\begin{tabular}{|l|l|c|l|}
\hline No & Moda & $\begin{array}{c}\text { Total Biaya } \\
\text { Perjalanan } \\
\text { (Rp) }\end{array}$ & $\begin{array}{c}\text { Total Lama } \\
\text { Perjalanan (Jam) }\end{array}$ \\
\hline 1 & Darat & $4,500,000$ & 83.33 \\
\hline 2 & Laut & $7,500,000$ & 86.67 \\
\hline 3 & Udara & $19,500,000$ & 60.17 \\
\hline 4 & Kereta Api & $5,500,000$ & 83.33 \\
\hline
\end{tabular}


Hasil Sortir Total biaya perjalanan terendah pengiriman barang:

1. Moda Kereta Api

2. Moda Laut

3. Moda Darat

4. Moda Udara

Dan Hasil Sortir Total waktu terpendek perjalanan pengiriman barang:

1. Moda Udara

2. Moda Kereta Api

3. Moda Darat

4. Moda Laut

Sehingga dapat disimpulkan bahwa Moda Kereta Api merupakan Moda paling efektif yang dapat digunakan untuk pengiriman dari Kota Surabaya ke Kota Jakarta. Untuk perhitungan Kota lain dapat disimulasikan dengan cara yang sama.

\section{KESIMPULAN}

Kesimpulan yang diperoleh dari studi kasus ini adalah sebagai berikut:

1. Transportasi multimoda yang dapat diterapkan adalah perjalanan pengiriman barang pada jalur utama, yaitu pengiriman barang dari pabrik di kota asal menuju kota tujuan untuk didistribusikan ke semua toko.

2. Sedangkan optimasi menggunakan Algoritma Kruskal digunakan untuk angkutan satu moda dalam pendistribusian barang dalam kota atau luar kota.

3. Pada optimasi angkutan multimoda, hal yang dipertimbangkan adalah biaya dan waktu perjalanannya dari 4 moda, yaitu Darat, Laut, Udara dan Kereta Api.

4. Jumlah kota tujuan yang menggunakan multimoda ditetapkan 1 kota tujuan.

5. Pada distribusi antar toko dalam/luar kota yang menggunakan satu moda, jumlah toko yang akan menjadi tujuan, bersifat dinamis sesuai masukan user.

6. Pada optimasi angkutan satu moda, hal yang dipertimbangkan adalah rute terdekat agar dapat mengunjungi setiap toko tepat satu kali.

7. Sistem optimasi ini, dapat digunakan oleh semua jenis pengiriman barang yang bersifat tertutup dan tidak mudah basi.

\section{DAFTAR PUSTAKA}

Hamilton, Sir William Rowan. Encyclopedia Britannica. Diakses tanggal 8 Juni 2014. Munir, Rinaldi. Matematika Diskrit Revisi Kelima. Bandung : INFORMATIKA. 2012.

Kruskal, J. B. On the shortest spanning subtree of a graph and the traveling salesman problem". Proceedings of the American Mathematical Society 7. 1956. 